ORCID: 0000-0002-0032-9944

Uniwersytet Warmińsko-Mazurski w Olsztynie

marzenna.nowicka@uwm.edu.pl

\title{
Orientowanie się w przestrzeni bez przestrzeni - o budowaniu świadomości przestrzennej w edukacji wczesnoszkolnej
}

\begin{abstract}
Summary
Orientating in a space without space about building spatial awareness in early school education

Orientation in physical space is a skill that allows functioning well in everyday life. The task of the school is to support this skill. The article presents the results of an analysis of 3 packages of school textbooks intended for I-III classes of primary school. It was agreed that textbook instructions concerning building spatial awareness are of a narrow instrumental nature and are focused solely on achieving efficiency in school understanding. The focus is on static situations organized in the classroom and exercises on the plane. Children acquire only knowledge about space, and do not accumulate useful experience related to everyday functioning in it.
\end{abstract}

Keywords: spatial orientation, spatial awareness, early school education, textbooks

Słowa kluczowe: orientacja przestrzenna, świadomość przestrzenna, edukacja wczesnoszkolna, podręczniki

Relacja człowiek-przestrzeń jest zagadnieniem badawczym rozpatrywanym na gruncie wielu dyscyplin naukowych. W zależności od przyjętej perspektywy różnie się tę przestrzeń identyfikuje i określa (Izdebska 2015). W niniejszym artykule przedstawiam rozważania dotyczące orientowania się dziecka w przestrzeni fizykalnej, środowiskowej. Odwołuję się zatem do podstawowego wzorca dla koncepcji przestrzeni w naukach społecznych, jakim jest trójwymiarowa przestrzeń fizyczna (Sack 1980, za: Lisowski 2014: 11). Koncentracja na kategoriach fizycznych i geometrycznych nie oznacza odcinania się od oczywistych powiązań z kontekstem społeczno-kulturowego wytwarzania przestrzeni (Rembowska 2013: 69). Orientacja w przestrzeni, rozumianej jako „ogół stosunków zachodzących między współwystępującymi przedmiotami materialnymi, ich rozmiarami i kształtami" (Izdebska 2015: 11), jest warunkiem dobrego funkcjonowania człowieka w otaczającej rzeczywistości.

Orientacja przestrzenna, będąca czynnością psychiczną związaną z spostrzeganiem, rozumiana jest jako proces uświadomienia położenia ciała w przestrzeni (Vetulani, Mazurek 2015). Orientację przestrzenną określa się jako: „,kontrolę ciała wobec otoczenia 
w odniesieniu do miejsc, rzeczy i osób: zdawanie sobie sprawy z rozmiarów i kształtów otaczającej przestrzeni oraz wielkości, kształtów i rozmieszczenia w niej przedmiotów" (Mihilewicz 1999: 39). Z przedstawionej definicji wynika, że częścią orientacji przestrzennej jest świadomość przestrzenna, oznaczająca świadomość lokalizacji obiektów wokół ciała. W literaturze przedmiotu - podobnie jak to przyjęłam w niniejszym artykule - pojęcia te często są utożsamiane i najogólniej interpretowane jako zdolność: rozumienia relacji między obiektami w przestrzeni, ich interpretowania, werbalizowania i wykorzystywania w działaniu (Głodkowska 2000: 34-35). Ściśle z tym powiązane jest Gardnerowskie wyróżnienie inteligencji wizualno-przestrzennej jako zdolności tworzenia umysłowych modeli świata przestrzennego, ich transformowania, modyfikowania i wizualizowania (Gardner i in. 2001: 158). W badaniach funkcjonowania w przestrzeni używane jest też określenie „kompetencja przestrzenna”, traktowana jako połączenie dwóch komponentów: wyobraźni przestrzennej (wizualizacja układów przestrzennych i operowanie nimi) i orientacji przestrzennej (Guzy 2010: 111). W niniejszym artykule odwołuję się do szerszego ujęcia kompetencji przestrzennych, wykorzystywanego przez Rolanda Meighana (1993: 94), dla którego oznaczają one posiadanie dwojakiego rodzaju zdolności: po pierwsze zdolności jednostki do bycia świadomą jej otoczenia i jego wpływu na nią, a po drugie zdolności do wykorzystywania i zmieniania otoczenia do realizacji własnych celów.

Poznawanie i zdobywanie orientacji w przestrzeni jest złożonym i długotrwałym procesem, uzależnionym od ukształtowanych spostrzeżeń, wyobrażeń i pojęć. W ontogenezie na kształtowanie orientacji w przestrzeni wpływ ma kilka sprawności: koordynacja między zmysłami (przestrzeń jest odbierana wielozmysłowo), poczucie stałości otaczających obiektów (jest wyznaczana przez relacje między obiektami), umiejętności lokomocyjne i manipulacyjne (jest poznawana w działaniu) oraz sprawność werbalna w opisywaniu relacji przestrzennych (jej poznawanie pozostaje w związku z rozwojem mowy) (Adamski 2007: 78). Zgodnie z ustaleniami Jeana Piageta spójna przestrzeń sensoryczno-motoryczna najbliższego otoczenia tworzy się w ciągu pierwszych 18 miesięcy życia, a praktyczny świat dziecka jest pierwotnie ukształtowany przez przedmioty stałe. W okresie tym wyróżnia się trzy ważne dla percepcji przestrzeni fazy (Vurpillot 1991: 288). Od narodzin do czwartego miesiąca dziecko spostrzega świat jako pewną „,całość heterogenicznych przestrzeni, przy czym wszystkie one skupione są na własnym ciele dziecka" (Piaget, Inhelder 1993: 17). Przestrzeń ustna, dotykowa, wzrokowa, słuchowa, postawy i wrażenia czasowe nie są ze sobą skoordynowane i pochodzące z nich dane sensoryczne nie pozostają ze sobą w żadnych relacjach. Dziecko nie odróżnia też własnych ruchów od ruchów przedmiotów, a zmiany perspektywy postrzega jako zmiany samych przedmiotów (Wadsworth 1998: 48). Od około czwartego miesiąca życia pojawia się koordynacja między chwytaniem i widzeniem, a potem między innymi danymi sensorycznymi (Vurpillot 1991: 288). Dziecko chwyta przedmioty i nimi manipuluje. Jednak przedmioty nie mają jeszcze cechy stałości trwania, brakuje też rozróżniania zmian stanu fizycznego i położenia przestrzennego. Trzecia faza, rozpoczynająca się od ok. 8.-9. miesiąca życia dziecka, wiąże się z kształtowaniem 
się percepcyjnej stałości wielkości oraz stałości kształtu przedmiotu. Dziecko rozpoznaje przedmiot mimo przekształceń, jakim ulega obraz tego przedmiotu na siatkówce oka w zależności od oddalania czy obrotu (Vurpillot 1991: 288). Jak już wspomniano, zwieńczenie przebytych etapów w postaci spójnego szkieletu przestrzeni praktycznej następuje ok. 18. miesiąca życia dziecka, choć odniesienia w tej przestrzeni nadal są skoncentrowane na własnym ciele dziecka, a punkty widzenia nie są skoordynowane. W następnych latach dzięki rozwojowi zdolności tworzenia reprezentacji umysłowych możliwy staje się zewnętrzny wobec podmiotu i przedmiotów układ odniesienia. Od ok. 7. roku życia dziecka pierwotna, niehomogeniczna, nieizotropowa (ma wymiary uprzywilejowane), nieciągła i ześrodkowana na podmiocie (nie da się jej zbudować z dowolnego punktu) przestrzeń zostaje konstruowana od nowa w przestrzeń racjonalną (Piaget 1966: 53). W tym czasie pojawia się też pojęcie i reprezentacja perspektywy (zmniejszanie w odległości, zanikanie itd.). Ostatecznie pojęcie przestrzeni zostaje ukształtowane ok. 9.-10. roku życia (Piaget, Inhelder 1993: 38). Badania prowadzone w nurcie neopiagetowskim wskazują, że kompetencje małych dzieci w zakresie rozumowania są większe, niż zakładał Piaget. Dzieci wyraźnie wcześniej rozumieją: pojęcie stałości przedmiotów, fizyczne właściwości przedmiotów znajdujących się poza zasięgiem ich wzroku, wykazują zdolność zmiany własnej perspektywy w obszarze percepcji, są w stanie uwzględniać stan emocjonalny i przekonania innych osób (Tarvis, Wade 1999).

W nawiązaniu do teorii Piageta Edyta Gruszczyk-Kolczyńska i Ewa Czaplewska (1996: 33) potwierdziły, że rozwój dziecięcych kompetencji w zakresie orientacji przestrzennej jest ściśle powiązany z umiejętnością myślenia operacyjnego i stopniowym rozwojem decentracji. Przebieg tego rozwoju charakteryzuje zachowanie kolejności przebiegającej: od różnicowania $j a$ i otoczenia, znajomości schematu własnego ciała, przez rozróżnianie kierunków oraz położenia przedmiotów w stosunku do własnego ciała, następnie w stosunku do drugiej osoby, aż do określania położenia obiektów względem drugich i wyznaczania kierunków od lub do wybranego przedmiotu (Gruszczyk-Kolczyńska, Czaplewska 1996: 33).

Orientacja w przestrzeni fizycznej jest podstawową zdolnością poznawczą, permanentnie i często w nieuświadamiany sposób wykorzystywaną niezależnie od wieku, warunkującą podejmowanie różnorodnych działań. Ocena odległości, położenia, rozmiaru i relacji pomiędzy obiektami w przestrzeni jest niezbędna m.in. w takich czynnościach, jak: przemieszczanie się, orientacja we własnym położeniu, prowadzenie i parkowanie pojazdów, czytanie tabel, diagramów czy map i ich tworzenie, budowanie modeli na podstawie instrukcji, rysowanie, projektowanie przestrzeni, korzystanie $\mathrm{z}$ aplikacji telefonicznych itp. Kształtowanie orientacji przestrzennej jest również ważnym zagadnieniem w edukacji dziecka, zdolności wizualno-przestrzenne bowiem są powiązane z nabywaniem umiejętności językowych (Guzy 2015), matematycznych (Derdzikowska 2009) i są predyktorami dysleksji, dysgrafii i innego rodzaju trudności w uczeniu się (Szczepkowska 2017). Ocena poziomu orientacji przestrzennej często wchodzi w skład badania gotowości szkolnej uczniów na progu szkoły podstawowej (Oszwa 2006). Wobec wagi orientacji 
przestrzennej w codziennych doświadczeniach warto rozważyć, jak przebiega szkolne wspieranie nabywania tej umiejętności przez dzieci.

\section{O projekcie badawczym}

Głównym celem prezentowanych w niniejszym artykule badań była identyfikacja modelu kształcenia orientacji przestrzennej uczniów promowanego w podręcznikach przeznaczonych dla edukacji wczesnoszkolnej. Problem główny zawierał się w pytaniu: Jak w świetle podręczników szkolnych kształcona jest orientacja przestrzenna uczniów klas początkowych?

W szczególności rekonstruowałam kwestie dotyczące tego, jakie polecenia odnośnie do kształcenia świadomości przestrzennej są obecne w podręcznikach szkolnych, czym się charakteryzują i jakich obszarów dotyczą. Interesowało mnie również mapowanie nieobecności, braków poleceń, które w świetle dostępnej literatury przedmiotu i własnych dociekań mogłyby również posłużyć wzmocnieniu potencjału ucznia w zakresie świadomości przestrzennej.

W badaniach zastosowałam analizę dokumentów zastanych (Łuczewski, Bednarz-Łuczewska 2012). Zbudowałam wstępny korpus danych, biorąc pod uwagę dostępność oraz kompletność materiałów do analizy. Przeanalizowałam trzy pakiety podręczników i ćwiczeń dla klasy I, II i III szkoły podstawowej, dopuszczonych przez MEN po ostatniej reformie programowej z 2017 r. Pochodziły one z wydawnictw: Nowa Era (Elementarz odkrywców), Didasko (Ja, ty - my), Mac Edukacja (Oto ja). W zależności od klasy kolejne serie podręczników miały dodatkowe dookreślające podtytuły.

\section{Kształcenie orientacji przestrzennej uczniów w świetle poleceń z podręczników szkolnych}

Budowanie reprezentacji przestrzeni w umysłach dzieci odbywa się głównie w obszarze edukacji matematycznej i przyrodniczej. Na zajęciach matematycznych obejmuje ono wyznaczanie kierunków: góra-dół, przód-tył, lewa-prawa i określanie z ich uwzględnieniem położenia różnych obiektów, głównie wobec osoby dziecka. Zgodnie z zapisami podstawy programowej reprezentowana w podręcznikach edukacja przyrodnicza rozszerza ten zakres do określania lokalizacji obiektów z większego dystansu, z uwzględnieniem kierunków świata, orientacji na planie i różnego typu mapach.

W wyniku analizy treści podręczników szkolnych wyodrębniłam następujące cechy kształcenia orientacji przestrzennej dzieci:

- koncentrowanie się na statycznych sytuacjach w przestrzeni klasy szkolnej;

- koncentracja na płaszczyźnie;

- transmisja wiedzy i ograniczanie doświadczeń dziecka;

- kształcenie umiejętności typowo szkolnych;

- separacja od środowiska życia dziecka. 


\section{Koncentrowanie się na statycznych sytuacjach w przestrzeni klasy szkolnej}

W zakresie edukacji matematycznej w analizowanych podręcznikach obecne są głównie zadania dotyczące orientacji dziecka w kierunkach wyznaczanych od siebie, położeniu obiektów względem własnego ciała lub innego obserwatora oraz wzajemnego położenia obiektów. Co charakterystyczne, ćwiczenia te dotyczą sytuacji statycznych, w których obserwowane obiekty leżą lub stoją nieruchomo. Zupełnie brakuje sytuacji dynamicznych, związanych z ruchem osób i obiektów w kierunku lewym bądź prawym, skrętów w prawo lub lewo, obracaniem wokół osi (por. Semadeni 2013, 2015: 133-143). Co więcej, ćwiczeniom tym nie poświęca się zbyt wiele miejsca, a ich warianty są bardzo podobne do siebie we wszystkich analizowanych podręcznikach.

Określanie relacji między przedmiotami odbywa się głównie na podstawie analizy położenia przedmiotów na rysunku bądź ilustracji, rzadziej polecenia dotyczą obiektów rzeczywistych. Dzieci mają przy tym używać pojęć, które już dawno powinny mieć opanowane w okresie przedszkolnym: za, obok, przed, nad itp. Typowe polecenia dla dzieci siedmioletnich dotyczą w oczywisty sposób sfery ich aktualnego rozwoju i nie stanowią dla dziecka żadnego intelektualnego wyzwania. W zależności od podręcznika dzieciom przedstawia się scenki z parku, z łąki, z ulicy, ze sklepu itp. i stawia pytania:

Gdzie schował się pies? Gdzie stoi wózek? Kto idzie przed panem? Gdzie leży piłka? Co stoi obok ławki? Co fruwa nad łąką? Co fruwa wyżej niż ważka? A co niżej? Co jest nad półką z makaronem, a co pod półką z dżemami.

W podręcznikach zwraca się szczególną uwagę na orientację dziecka w ustalaniu stron lewa-prawa bądź położenia obiektów na lewo lub prawo od danego przedmiotu lub osoby. Tu również dzieci głównie analizują położenie osób czy zwierząt oraz przedmiotów przedstawionych na ilustracjach, odpowiadając na pytania:

W którą stronę patrzy małpka, w którą miś? W którą stronę lecą ptaki, a w którą idą ludzie? Narysuj coś po lewej stronie piłki itp.

Co ważne, rozważa się też względność strony prawej i lewej, zarówno na ilustracjach, jak i w przestrzeni klasy szkolnej:

Który pajac stoi przodem, a który tyłem do ciebie? Stań najpierw tak jak pajac z prawej strony kartki. Podnieś prawą rękę. Potem stań tak jak pajac z lewej strony kartki. Podnieś prawą rękę. Potem stań jak pajac z lewej strony kartki. Podnieś prawą rękę. Wskaż prawą rękę każdego pajaca. Przy której nodze jednego i drugiego pajaca leży piłka? (NE, P, 1, M, I, s. 6) ${ }^{1}$

1 Przy cytatach zastosowano kody odnośnie do analizowanych podręczników, kolejno oznaczając: wydawnictwo (Nowa Era - NE, Didasko - D; Mac Edukacja - ME), podręcznik/ćwiczenia (P/C), część 
Stań naprzeciwko kolegi i powiedz, co znajduje się w klasie po twojej lewej stronie. Powiedz, co się znajduje po lewej stronie kolegi. Co zauważasz? (ME, P, 1, M-R, II, s. 6)

Dwa powyższe przykłady dotyczą gromadzenia bardzo cennych bezpośrednich doświadczeń, jednak nasycenie nimi badanych podręczników można uznać wyłącznie za sygnalne. Dzieci nie tylko nie przemieszczają się w przestrzeni klasy szkolnej, ale również z niej nie wychodzą. Bardzo brakuje poleceń, by np. opuścić budynek i iść w prawo, w lewo, skręcać w określonym kierunku. Dzieci nie badają, co jest na prawo czy lewo w drodze do szkoły w powiązaniu z tym, co zaobserwują w drodze powrotnej ze szkoły do domu. Nie ustalają też kierunku ruchu obiektów, zarówno tych z klasy szkolnej, jak i poza nią: nie obracają przedmiotami, by ustalić kierunek obrotu (np. zakrętkami na butelce), nie określają kierunku ruchu pojazdów na ulicy w stosunku do obserwatora i kierowcy itp. Jak wynika z analizy podręczników, tylko incydentalnie na zajęciach z informatyki zdarzy się dzieciom brać udział w zabawie, w której będą mogły w dynamiczny sposób doskonalić swoją orientację.

Podzielcie się na 3-4-osobowe grupy. Jedna osoba w każdej grupie będzie robotem. Pozostali uczniowie to programiści, czyli osoby, które będą programowały robota, to znaczy wydawały mu polecenia. Pamiętajcie, że wasze roboty znają tylko polecenia Krok oraz Skręt w prawo i Skręt w lewo. (NE, P, In, I, s. 18)

\section{Koncentracja na plaszczyźnie}

Charakterystycznym rysem proponowanego w podręcznikach modelu rozwijania dziecięcej orientacji w otaczającej przestrzeni fizycznej jest koncentracja na płaszczyźnie kartki w zeszycie, ćwiczeniach czy podręczniku. Kartka służy do utrwalania orientacji, gdzie jest strona lewa czy prawa, góra czy dół, północ czy południe itd. Typowym poleceniem, obecnym w każdym $\mathrm{z}$ analizowanych pakietów, jest rysowanie strzałek w różnych kierunkach na pokratkowanej kartce. Dzieci mają ustalać drogi w labiryncie, korzystając z określeń: w prawo, w lewo, w górę, w dół. Oto przykład takiego polecenia:

Odczytaj, jak powinna się poruszać mama jeż, by spotkać się ze swoimi dziećmi. Zapisz w zeszycie za pomocą strzałek, jak przebiegałaby trasa taty jeża. (ME, P, 1, M-R, I, s. 15)

Można użyć określenia, że koncentracja na płaszczyźnie kartki papieru „spłaszcza” świat dziecka i utrwala kompetencje dotyczące orientacji wyłącznie w dwóch wymiarach. W podręcznikach brakuje uwzględniania trójwymiarowej przestrzeni fizycznej wokół dziecka i postrzegania przez nie perspektywy. Uczniowie zajmują się obrazkami, a nie realnymi przedmiotami usytuowanymi wokół nich. Najczęściej mają przyglądać się tylko

podręcznika/ćwiczeń, jeśli jest (1-4 lub A, B), rodzaj edukacji (polonistyczna - Po, przyrodnicza - R, społeczna - S, matematyczna - M, informatyczna - In), klasę (I-III), stronę (s.). 
ilustracjom w podręcznikach, na których przedstawia się mierzenie, bądź zgodnie z poleceniami mierzyć długość narysowanych ołówków, pasków papieru, kredek, sznurków, łopatek czy butów itp. Do zupełnej rzadkości należą polecenia typu:

Zorganizujcie w klasie podobne zabawy z mierzeniem. (NE, P, 2, M, I, s. 33)

Co charakterystyczne, sytuacje mierzenia są przedstawiane w podręcznikach tak, jakby przedmioty w otoczeniu dziecka były wyłącznie płaskie, bo dzieciom najczęściej poleca się przedstawienie tylko jednego wymiaru, np. wysokości domów przedstawionych na ilustracji lub grubości pieńków drzew z fotografii. Takie zadania mocno utrwalają błędne postrzeganie obiektów. Ogólnie przestrzenność ukazywana jest na nielicznych przykładach i niestety nawet wtedy, gdy rozważa się z dziećmi trzy wymiary, to takie zadania nie zapobiegają utrwalaniu błędnych skojarzeń. $\mathrm{W}$ jednym z podręczników przedstawiono fotografie kawałka drewna, budowli z piasku i łopatki do piasku. Polecenia obok są następujące:

Zmierz szerokość i długość kawałka drewna przedstawionego na zdjęciu.

Zmierz i podaj wysokość zamku z piasku oraz długość łopatki.

Zapisz pomiary w zeszycie. Zwróć uwagę, kiedy mierzysz długość, kiedy szerokość, a kiedy wysokość. Znajdź różne przedmioty w klasie i w domu. Zmierz je i zapisz wynik pomiarów w zeszycie. Zaznacz, czy był to pomiar szerokości, długości czy wysokości. (ME, P, 2, M-R, II, s. 34)

Ukazane w przytoczonym przykładzie polecenia są tak skonstruowane, że mogą sugerować dzieciom, iż niektóre przedmioty mają dwa lub nawet tylko jeden wymiar. Po wykonaniu takich ćwiczeń dziecko może nabrać przekonania, że blat jego ławki to prostokąt, bo ma dwa wymiary - długość i szerokość. Autorzy poleceń z tego podręcznika dodatkowo podkreślają odrębność mierzenia długości, wysokości i szerokości, choć te wielkości czasami traktuje się zamiennie².

Przywiązanie do płaskiego interpretowania wymiarów przedmiotów jest połączone z dużym nasyceniem podręczników ilustracjami i kompilacją fotografii, na których zupełnie zaburzone są proporcje poszczególnych obiektów. W wielu przypadkach na wspólnej ilustracji przedstawiane są przedmioty czy zwierzęta bez zachowania jednej skali ich wymiarów: duże króliki obok małych drzew, tukany większe od leniwców, duże wachlarze obok małych parasoli, małe kwiatki w towarzystwie wielkich biedronek itp.

W badanych podręcznikach w małym nasyceniu, lecz są jednak obecne sytuacje zaburzania postrzegania perspektywy przez dzieci. Na przykład w jednym z nich przedstawiony jest plan miasta wykonany z typowymi błędami w percepcji dziecka do 8.-9. roku życia (Szemińska 1981: 231-232). Narysowane na nim samochody jadące po jezdni

2 Na przykład w prostopadłościanie, jakim jest pudełko zapałek, szerokość tego pudełka można również traktować jako jego wysokość itp. 
w lewo są przedstawione do góry nogami w stosunku do tych jadących w prawo, domy są zawsze prostopadle do drogi, a więc czasami do góry nogami wobec obserwatora (NE, P, 1, M, III, s. 6). Podobnego typu i inne zniekształcenia można zobaczyć również na planach zamieszczanych w pozostałych badanych podręcznikach. Zgodnie z ustaleniami Piageta dzieci dość późno uwzględniają perspektywę, jednak organizowanie odpowiednich doświadczeń znacznie przyspiesza postępy w rozumieniu stosunków przestrzennych (Szemińska 1981: 229-231). Szkoda, że autorzy podręczników nie biorą pod uwagę tej prawidłowości.

\section{Koncentracja na przekazie wiedzy i ograniczanie doświadczeń dziecka}

Budowanie reprezentacji przestrzeni w umysłach uczniów klas początkowych opiera się głównie na przekazie wiedzy, co szczególnie uwidacznia się w ramach edukacji środowiskowej, dotyczącej orientacji dzieci w najbliższej okolicy. Analizowane podręczniki są silnie nasycone informacjami dotyczącymi: lokalizacji, rozmieszczenia, wielkości, ukształtowania, sąsiadowania różnych miejsc czy obiektów w terenie. Wiedza o obiektach w środowisku fizycznym jest wzbogacana kolorowymi zdjęciami, rysunkami, mapami i planami. Niestety polecenia samodzielnego eksplorowania przestrzeni należą do rzadkości. Dominuje przekaz wiedzy i postępowanie według wzoru. Dobitnie obrazuje to przykład z jednego z podręczników, w którym dzieci mają tylko odtworzyć w ćwiczeniach informację podaną $\mathrm{w}$ podręczniku:

Przeczytaj tekst i powiedz, jakie są główne kierunki świata i jak je można wyznaczyć.

Są cztery kierunki świata: wschód, zachód, północ, południe. Słońce wschodzi na wschodzie, a zachodzi na zachodzie. Jeśli ustawisz się tak, że twoja prawa ręka będzie wskazywała miejsce wschodu Słońca, czyli wschód, to lewa wskaże zachód. Przed tobą będzie północ, a za tobą południe. (ME, P, 1, M-R, III, s. 36)

Poniżej na ilustracji przedstawione jest dziecko stojące tyłem do odbiorcy, a przodem do wielkiego Słońca. Dziecko ma rozpostarte ręce. Wokół niego widnieją adekwatne podpisy: północ, południe, wschód i zachód. W odpowiadających podręcznikowi ćwiczeniach znajduje się dokładnie taka sama ilustracja i polecenie:

Wytnij (s. 95) i przyklej w odpowiednich miejscach brakujące nazwy kierunków geograficznych, możesz skorzystać z podręcznika. (ME, C, 1, M-R, III, s. 36)

Całe ćwiczenie polega zatem na dokładnym zapamiętaniu informacji z podręcznika i ich odwzorowaniu w ćwiczeniach. Nie ma to żadnego związku z praktycznym działaniem dziecka i kształtowaniem umiejętności wyznaczania kierunków w otaczającym go środowisku.

W podręcznikach właściwie nie sugeruje się gromadzenia osobistych doświadczeń, dzieci nie badają map, niczego nie przedstawiają w postaci planów i nie projektują. Jak 
w przytoczonym przykładzie, nie rysują tras własnych pieszych wypraw, ale na podstawie czytanki mają schematycznie przedstawiać szlaki wyimaginowanych bohaterów:

Na podstawie tekstu $Z$ wiosną na ratunek narysuj trasę wędrówki Jaśka. (NE, C, 3, III, s. 64)

Transmisyjność nauczania wzmacniają też polecenia odwołujące się do pamięci dzieci, do tego, co już kiedyś widziały, do domniemanych doświadczeń zgromadzonych poza szkołą. Na przykład zamiast badać lokalizację obiektów w drodze do szkoły uczniowie mają w ramach ćwiczeń językowych tylko opisywać ją z pamięci na czterech wolnych linijkach w ćwiczeniach:

Opisz swoją drogę z domu do szkoły, babci lub kolegi. (D, C, A, P, II, s. 81)

Ubezwłasnowolnianie uczniów w poznawaniu przestrzeni i cementowanie pojęć na podstawie przekazu bez ich osobistego badania jawią się jako kardynalne błędy w kształtowaniu świadomości przestrzennej dziecka.

\section{Ksztalcenie umiejętności typowo szkolnych}

Podręcznikowy przekaz wiedzy dotyczący orientacji dziecka w przestrzeni wzmacniany jest silną koncentracją na kształceniu umiejętności typowo szkolnych z tym związanych, z pewnością przydatnych na dalszych etapach edukacji, choć niekoniecznie możliwych do przełożenia na praktykę pozaszkolną.

Na przykład w badanych podręcznikach ukazywane są różne mapy: fizyczne i polityczne Polski i Europy lub tematyczne: pogody, zamków w Polsce, parków narodowych itp. Pytania, które się przy nich pojawiają, można uznać wręcz za kanoniczne dla każdego poziomu kształcenia, a zaczynają się właśnie na poziomie wczesnoszkolnym:

Odczytaj nazwy miast.

Wskaż stolicę Polski.

Pokaż na mapie morze, góry, jeziora.

Znajdź na mapie największe polskie rzeki i odczytaj ich nazwy.

Pokaż na globusie biegun północny - Arktyka, i południowy - Antarktyda.

Polecenia w podręcznikach są wzmacniane stosownymi zadaniami w ćwiczeniach. Aby lepiej utrwalić poznane pojęcia, dzieci mają układać zdania z nazwami kierunków geograficznych lub uzupełniać zapisy:

Góry na mapie oznaczamy kolorem ..., niziny kolorem ..., a wyżyny ... (D, C, B, Po, II, s. 17)

Na podstawie mapy Europy napisz, przez jakie kraje trzeba przejechać, żeby dostać się z Polski do Włoch. (NE, C, 4, Po-R-S, III, s. 64) 
Napisz nazwy państw, z którymi graniczy Polska: na wschodzie ..., na zachodzie ..., na południu ... (D, C, B, R, III, s. 169).

Kształcenie umiejętności typowo szkolnych jaskrawo obrazuje następujący przykład. Polecenie zawiera bardzo rzadką w badanych podręcznikach sugestię opuszczenia budynku szkolnego i wyjścia w teren, gdzie dzieci mają się nauczyć praktycznie wyznaczać strony świata. Jednak żadne z poleceń nie łączy nabytych umiejętności z konkretnymi sytuacjami, w których dzieci mogłyby je wykorzystać:

1. Wyjdźcie w słoneczny dzień w południe przed szkołę. Zabierzcie ze sobą kompas. Wyznaczcie najpierw kierunek północny, obserwując wasze cienie, a następnie sprawdźcie za pomocą kompasu, czy zrobiliście to poprawnie.

2. Poszukajcie na drzewach lub kamieniach mchu. Wykorzystajcie go do określenia kierunków.

3. Powiedz, co znajduje się na wschód od budynku szkoły, a co na południe. (NE, P, 3, III, s. 62)

Przykład polecenia uwidacznia koncentrację na mechanicznym opanowaniu konkretnych umiejętności. Istnieje bardzo duże prawdopodobieństwo, że określanie i wyznaczanie kierunków świata będą się jawić dzieciom wyłącznie jako sprawności, od których zależy ocena szkolna. Według czytanek podręcznikowych wiedza o tym, jak wyznaczyć północ, potrzebna jest tylko podczas harcerskich wypraw po lesie. W przedstawionym przykładzie interesujące dla dzieci mogłoby się okazać: badanie położenia Słońca w drodze do celu zlokalizowanego w określonym kierunku i z powrotem, ustalanie kierunków dróg wyjazdu z własnej miejscowości i potencjalnych miejsc docelowych podróży itp.

Brak kontekstu praktycznego umiejętności ćwiczonych w szkole powoduje, że jawią się one dziecku jako zupełnie nieprzydatne i ostatecznie nie przełożą się na budowanie jego świadomości przestrzennej.

\section{Separacja od środowiska życia dziecka}

Ostatnią cechą kształcenia świadomości przestrzennej dziecka w świetle badanych podręczników jest oddzielenie tego kształcenia od środowiska, w którym dziecko żyje. Polecenia zawarte w podręcznikach dotyczą sytuacji poglądowych, zlokalizowanych w nierealnym świecie czytankowych bohaterów. Dzieci nie rysują tras własnych pieszych wędrówek, nie badają planów własnych miejscowości, ale pozostając w świecie fikcji, mają np. wykonać następujące polecenia:

Na podstawie tekstu $Z$ wiosna na ratunek narysuj trasę wędrówki Jaśka. (NE, C, 3, Po-R-S, III, s. 64)

Napisz, dokąd dojdzie Ula, jeżeli po wyjściu z domu pójdzie ul. Krótką, później skręci w prawo - w ul. Makową, następnie w lewo (...). (D, C, A, Po, II, s. 81) 
Przyjrzyj się fragmentowi mapy miasta. Wypisz nazwy ulic prostopadłych i równoległych do podanych. Ulice równoległe do ulicy Jaśminowej ... Ulice prostopadłe do ulicy Jaśminowej ... (ME, C, 1, M-R, III, s. 52)

Odszukaj i zaznacz na planie sklepy polecane przez Stefanię. Uzupełnij zdania. Użyj określeń: równoległa, prostopadła. Ulica Ludna jest ... do ulicy Dzikiej. Ulica Słodka jest ... do ulicy Poziomki. (D, C, 1, M, III, s. 97)

Dzieci mogą zapoznać się z fragmentami mapy miasta Warszawy, by lokalizować na niej różne obiekty, równocześnie nie sugeruje się im pracy z mapą własnego miasta. Mają analizować plany obcych osiedli i szukać na nich miejsc do bezpiecznej zabawy, ale nie poleca im się badania planów własnych okolic i poszukiwania takich bezpiecznych miejsc dla siebie. To, jak bardzo kształcenie umiejętności orientacyjnych nie dotyczy realnego życia samego dziecka, dobitnie obrazuje następujący przykład:

Na planie zaznaczono drogi Doroty, Eryka i Adama z ich domów do ulubionych miejsc wypoczynku z rodzicami. (...) Zaplanuj drogę wybranego dziecka tak, jak to robi nawigacja w samochodzie. Napisz w zeszycie takie komendy, by dzięki nim dziecko doszło do celu (ME, C, 2, M-R, III, s. 65)

Liczne powtarzające się polecenia tego typu w podręcznikach wskazują na konsekwencję w ograniczaniu okazji do rozwoju kompetencji dziecka w zakresie orientacji przestrzennej. Ignorowanie doświadczeń dziecka i izolowanie go od własnego środowiska pozwalają bowiem kształcić kompetencje jedynie w karłowatym wymiarze, pozostawiając otwarte pytanie co do ich użyteczności w życiu pozaszkolnym.

\section{Zakończenie}

Przedstawiony wynik jakościowej analizy treści w postaci stworzonego klucza kategoryzacyjnego ma wstępny charakter, dotyczy bowiem 3 z 11 pakietów podręczników zatwierdzonych przez MEN w wyniku ostatniej reformy programowej z 2017 r. Jednak już na tym poziomie można mówić o pewnych trendach w edukacji dzieci do orientowania się w przestrzeni.

Przede wszystkim trzeba zauważyć, że przedstawione analizy potwierdzają silne przywiązanie polskiej metodyki do piagetowskiego podejścia do rozwoju pojęć u dzieci, mimo obecności w literaturze odmiennych teorii, podkreślających specyfikę geometrycznego poznania (Swoboda 2006: 11). Jak już zaznaczono, badania neopiagetowskie w wielu kwestiach nie potwierdzają ustaleń Piageta, głównie co do wieku nabywania poszczególnych umiejętności, wskazując jednoznacznie na możliwość przyspieszenia rozwoju poprzez organizowanie różnorodnych sytuacji i wzbogacanie doświadczeń osobistych dziecka (Semadeni 2015: 146). Niestety zdecydowana większość zadań, z którymi styka się dziecko w podręcznikach, niewolniczo respektuje piagetowskie cezury wiekowe. 
Kształcenie orientacji przestrzennej w świetle podręczników szkolnych odbywa się w bardzo ograniczonym zakresie, ma techniczny charakter niepowiązany z nabywaniem doświadczeń w realnych sytuacjach, często ogranicza się do umiejętności już przez dziecko posiadanych, a przede wszystkim jest silnie skupione na dwóch wymiarach przestrzeni. Zachodzi tu zatem paradoksalna sytuacja, że uczymy orientacji przestrzennej bez pełnego odniesienia do tej przestrzeni - na płaskiej kartce papieru i w izolacji od najbliższego środowiska fizycznego. W zestawieniu z zachodnimi projektami budowania dziecięcej orientacji w świecie, o których pisze Teresa Sadoń-Osowiecka (2006), rodzima edukacja wydaje się bardzo zapóźniona. Polskie dzieci, w przeciwieństwie na przykład do uczniów brytyjskich, nie są motywowane do uważnych obserwacji przestrzeni wokół siebie, jej badania, oceniania, docierania do przyczyn istniejącego stanu rzeczy. W podręcznikach nie odnalazłam bloku poświęconego najbliższej okolicy, w którym dziecko miałoby szanse bliżej zapoznać się z przestrzenią własnej dzielnicy, drogą z domu do szkoły i z powrotem, przestrzenią wokół szkoły. Nie poszukuje się miejsc do spacerów, ważnych budynków do załatwiania różnych spraw, nie lokalizuje się sklepów osiedlowych itp. W podręcznikach brakuje także poleceń dotyczących prób przekształcania przestrzeni wokół. Dzieci nie są angażowane w budowanie przestrzeni, w której przebywają, we wprowadzanie do niej zmian, nie decydują, jak ma wyglądać ich plac zabaw, podwórko czy teren wokół szkoły $^{3}$. Nie przewiduje się ponadto szerokiego wykorzystywania narzędzi IT do nabywania kompetencji przestrzennych uczniów, spychając to zagadnienie wyłącznie do obszaru zajęć informatycznych i ćwiczeń skoncentrowanych na stronie technicznej. Tymczasem nowe technologie są integralną częścią świata współczesnych dzieci, a w ich urządzeniach dostępne są aplikacje ułatwiające nawigowanie podczas przemieszczania się w terenie. To nowy obszar kształcenia świadomości przestrzennej, zupełnie pomijany w edukacji wczesnoszkolnej.

Kończąc niniejsze rozważania, należy zauważyć, że podręczniki ukierunkowują pracę na zajęciach z dziećmi, ale ostatecznie o niej nie przesądzają. Pytanie o jakość edukacji W zakresie budowania świadomości przestrzennej uczniów pozostaje zatem otwarte, choć w świetle druzgocącej krytyki edukacji wczesnoszkolnej (por. Klus-Stańska (red.) 2014) trudno mieć duże nadzieje.

\section{Literatura}

Adamski A. (2007), Psychologiczny wymiar czasu i przestrzeni w ontogenezie człowieka. Bielsko-Biała, Compal.

Brzozowska-Brywczyńska M. (2013), Miasto (nie) dla dzieci? Przestrzeń miejska i problem dziecięcej partycypacji. W: B. Łaciak (red.), Dzieciństwo we wspótczesnej Polsce. Charakter przemian. Warszawa, Wydawnictwo Akademickie „Żak”.

3 Inspirujące badania dotyczące relacji dziecko - przestrzeń miejska prowadziły Maja Brzozowska-Brywczyńska (2013), Małgorzata Nieszczerzewska (2011), Agata Skórzyńska (2011) i in. 
Derdzikowska M. (2009), Wpływ orientacji przestrzennej - schematu ciała na umiejętności matematyczne. http://kwartalnikis.edu.pl/wplyw-orientacji-przestrzennej-zęajomosci-schematu-cialana-umiejetnosci-matematyczne/, 18.04.2020.

Gardner H., Kornhaber M.L., Wake W.K. (2001), Inteligencja. Wielorakie perspektywy. Warszawa, WSiP.

Głodkowska J. (2000), Pomóżmy dziecku z upośledzeniem umysłowym doświadczać przestrzeni. Orientacja przestrzenna $w$ teorii, diagnozie i rozwoju dziecka. Warszawa, Wydawnictwo WSPS.

Gruszczyk-Kolczyńska E., Czaplewska E. (1996), Orientacja przestrzenna: kompetencje dzieci, koncepcja ksztattowania orientacji przestrzennej. W: Kuczyńska-Kwapisz (red.), Rehabilitacja niewidomych i słabowidzacych. Warszawa, Centrum Metodyczne Pomocy Psychologiczno-Pedagogicznej Ministerstwa Edukacji Narodowej.

Guzy A. (2010), Kompetencja tekstotwórcza a wyobraźnia i orientacja przestrzenna uczniów klas III. W: B. Niesporek-Szamburska, M. Wójcik-Dudek (red.), Dziecko-język-tekst. Katowice, Wydawnictwo Uniwersytetu Śląskiego w Katowicach.

Guzy A. (2015), Czas na... kompetencje przestrzenna - nowy determinant kompetencji językowej. W: A. Guzy, D. Jagodzińska, M. Wacławek, A. Zok-Smoła, Czas na ... Język i dydaktyka w badaniach młodych naukowców. Katowice, Wydawnictwo Uniwersytetu Śląskiego w Katowicach.

Izdebska J. (2015), Wielowymiarowość przestrzeni życia wspótczesnego dziecka. „Zagadnienia Społeczne", 2(4).

Klus-Stańska D. (red.) (2014), (Anty)edukacja wczesnoszkolna. Kraków, Oficyna Wydawnicza „Impuls".

Lisowski A. (2014), Typy przestrzeni a geografia. „Prace Komisji Krajobrazu Kulturowego”, 24.

Łuczewski M., Bedanrz-Łuczewska P. (2012), Analiza dokumentów zastanych. W: D. Jemielniak (red.), Badania jakościowe. Metody i narzędzia. T. 2. Warszawa, Wydawnictwo Naukowe PWN.

Meighan R. (1993), Socjologia edukacji. Toruń, Wydawnictwo Uniwersytetu Mikołaja Kopernika.

Mihilewicz S. (1999), Schemat ciała i orientacja przestrzenna u dzieci z porażeniem mózgowym w młodszym wieku szkolnym. Wrocław, Dolnośląska Szkoła Wyższa Edukacji TWP.

Nieszczerzewska M. (2011), Topografia dziecięca, Od wielkomiejskiej ulicy do miejsc „,skrępowanej wyobraźni”. „Studia Kulturoznawcze”, 1.

Oszwa U. (2006), Rozwój i ocena umiejętności matematycznych dzieci sześcioletnich. Warszawa, Centrum Metodyczne Pomocy Psychologiczno-Pedagogicznej Ministerstwa Edukacji Narodowej.

Piaget J. (1966), Studia z psychologii dziecka. Warszawa, PWN.

Piaget J., Inhelder B. (1993), Psychologia dziecka. Wrocław, Siedmiogród.

Rembowska K. (2013), Perspektywy badań geograficznych w świetle dialektycznej koncepcji rzeczywistości społeczno-kulturowej. W: A. Suliborski (red.), Geografia w ujęciu humanistycznym. Wybór prac Krystyny Rembowskiej. Łódź, Wydawnictwo Uniwersytetu Łódzkiego.

Sadoń-Osowiecka T. (2006), Porównanie treści geograficznych w programach nauczania zintegrowanego polskiej szkoły $i$ w brytyjskim National Curriculum. Analiza krytyczna. W: D. Klus-Stańska, E. Szatan, D. Bronk (red.), Wczesna edukacja. Między schematem a poszukiwaniem nowych ujęć teoretyczno-badawczych. Gdańsk, Wydawnictwo Uniwersytetu Gdańskiego.

Schaffer H.R. (2005), Psychologia dziecka. Warszawa, Wydawnictwo Naukowe PWN.

Semadeni Z. (2013), Dziecinny egocentryzm poznawczy dotyczacy stosunków przestrzennych a kwestia kształtowania się niezmienników w umyśle ludzkim. „Przegląd Filozoficzny”, 2(86). 
Semadeni Z. (2015), Matematyka w edukacji poczatkowej-podejście konstruktywistyczne. W: Z. Semadeni, E. Gruszczyk-Kolczyńska, G. Treliński, B. Bugajska-Jaszczołt, M. Czajkowska, Matematyczna edukacja wczesnoszkolna. Teoria i praktyka. Kielce, Wydawnictwo Pedagogiczne ZNP.

Skórzyńska A. (2011), Sztuczki. Twórcza aktywność dziecka w marginalizowanych obszarach miejskich. „Studia Kulturoznawcze”, 1.

Swoboda E. (2006), Przestrzeń, regularności geometryczne i ksztalty w uczeniu się i nauczaniu dzieci. Rzeszów, Wydawnictwo Uniwersytetu Rzeszowskiego.

Szczepkowska E. (2017), Zaburzenia orientacji przestrzennej. „Życie Szkoły”, 28.

Szemińska A. (1981), Rozwój pojęć geometrycznych. W: Z. Semadeni (red.), Nauczanie początkowe matematyki. T. 1. Warszawa, WSiP.

Tarvis C., Wade C. (1999), Psychologia. Podejścia oraz koncepcje. Poznań, Zysk i S-ka.

Vetulani J., Mazurek M. (2015), Bez ograniczeń. Jak rządzi nami mózg. Warszawa, Grupa Wydawnicza PWN.

Vurpillot E. (1991), Percepcja przestrzeni. W: P. Fraisse, J. Piaget (red.), Zarys psychologii eksperymentalnej. Warszawa, PWN.

Wadsworth B.J. (1998), Teoria Piageta. Poznawczy i emocjonalny rozwój dziecka. Warszawa, WSiP. 